\title{
Growth performance of broiler chicks fed Aspergillus niger- fermented Terminalia catappa seed meal-based diet
}

\author{
N. O. MUHAMMAD * and O. B. OLOYEDE \\ Department of Biochemistry, University of Ilorin, Ilorin, Nigeria. \\ *Corresponding author, E-mail: alphamno2@yahoo.com, muno@unilorin.edu.ng; Tel: +2348033931900
}

\begin{abstract}
Forty-five, day-old broiler chicks with an initial average weight of $30.25 \pm 2.40 \mathrm{~g}$ were divided into three groups of fifteen animals each. The first group was placed on soybean-based (control) diet; the second group on raw (unfermented) T. catappa seed meal-based diet; and the third on A. niger-fermented T. catappa seed meal-based diet, for seven (7) weeks. Feed intake, feed conversion ratio, average weekly body weight gain and mortality were monitored. Though significantly lower $(\mathrm{p}<0.05)$ than the control, the animals placed on the fermented T. catappa seed meal-based diet had significant increase in their feed intake, feed conversion ratio and body weight gain when compared with those on the raw T. catappa seed meal-based diet. Thirty-three percent $(33 \%)$ mortality was recorded in broilers on raw T. catappa seed meal-based diet while no mortality was recorded in those placed on fermented seed meal-based and the control diets. The organ to body weight ratio of the broilers placed on the raw $T$. catappa seed meal-based diet indicate enlargement of the liver and gizzard in relation to the body when compared with both the control and the A. niger-fermented $T$. catappa seed meal-based diet. It is considered that the use of A. niger-fermented T. catappa seed meal as a source of protein in poultry feed, would enhance growth performance and prevent mortality.
\end{abstract}

(C) 2010 International Formulae Group. All rights reserved.

Keywords: Aspergillus niger, Terminalia catappa, fermentation, broilers, growth performance.

\section{INTRODUCTION}

Feed remains the most important factor in animal production; therefore efficient feeding programmes and maximum utilization of nutrients from feedstuffs are of primary concern to the feed industry. The use of a wide range of feed ingredients is likely to lead to better choice which may improve the efficiency of feedstuff utilization, and consequently lead to improvement in animal production (Classen and Cooper, 1998). The major objective of poultry feeding is to convert low quality feedstuffs into high quality animal protein for human consumption. In this respect, poultry outperforms all other livestock species, with current efficiency at close to 2:1 for broilers. The economic importance of poultry feeding becomes apparent when it is realised that 55 and $75 \%$ of the cost of production of egg and broiler meat respectively is associated with the cost of feed (Atteh, 2004).

The use of plant seeds as source of protein in poultry feeds has been documented (Atteh, 2002, 2004). Seeds from soybean (Vignia unguiculata) and groundnut (Arachis hypogea) have been used as plant sources of protein in both man and animal feed. However, the competition between man and animal over these conventional sources of protein has led to increase in the cost of these seeds and consequently, the exorbitant cost of animal protein in developing countries including Nigeria (Mohan and Janardhanan, 1995). Therefore, there is the need to search for alternative sources of protein for the 
poultry feed industry. Among the protein-rich seed that could be considered is that of Terminalia catappa.

Terminalia catappa is a tropical plant whose seed is very rich in protein and oil (Adewole and Olowookere, 1986). However, the existence of antinutrients in Terminalia catappa seed has been reported (Jeremiah, 1992; Muhammad and Oloyede, 2004; 2006; 2009). Antinutrients are natural or synthetic compounds that interfere with the digestion and absorption of nutrients. They include, among others, trypsin inhibitors and lectins found in legumes (Gilani et al., 2005), tannins (Beecher, 2003), phytic acid and oxalic acid (Hotz and Gibson, 2007) found in the seeds of many tropical plants. Manifestation of the effects of these compounds, called antinutrients, range from severe reduction in feed/food intake and nutrient utilization to profound neurological effects and even death (Butler, 1992; Osagie, 1998; Kamra, 2005). Terminalia catappa seed has been reported to contain antinutrients like phytate, oxalate and tannins and hydrocyanic acid (Jeremiah, 1992; Lin et al., 1999; Chen et al., 2000; Muhammad and Oloyede, 2006). Insoluble oxalate, phytate and tannins (particularly the condensed tannins) have been reported to be heat stable (Aderibigbe et al., 1997; Osagie, 1998; Reddy and Sathe, 2002) and are therefore not eliminated by heat during food processing.

Many traditional methods of food preparation such as fermentation, cooking, and malting increase the nutritive quality of plant foods through reducing certain antinutrients such as phytic acid, polyphenols, and oxalic acid (Hotz and Gibson, 2007). Such processing methods are widely-used in societies where cereals and legumes form a major part of the diet (Chavan and Kadam, 1989; Phillips, 1993). An important example of such processing is the fermentation of cassava to produce cassava flour: this fermentation reduces the levels of both toxins and antinutrients in the tuber (Oboh and Oladunmoye, 2007).

Fermentation, using fungi, has been reported to increase the protein content and reduce the antinutritional factors of plant materials and the consumption of such fermented materials, when used as an inclusion in animal feed, have been proved to be safe (Jacqueline et al., 1996; Muhammad et al., 2000; Belewu et al., 2002; Muhammad and Oloyede, 2006). The present study, therefore, was aimed at evaluating the effect of A. niger-fermented Terminalia catappa seed meal-based diet on the growth performance of broiler chicks.

\section{MATERIALS AND METHODS}

Ripe fruits of Terminalia catappa (authenticated at FRIN, Ibadan, Nigeria, with a voucher number of FHI 107767) were picked from the premises of the main campus of the University of Ilorin, Ilorin, Nigeria and, oven-dried at $60{ }^{\circ} \mathrm{C}$ and cracked to remove the seeds, using $125 \mathrm{~mm}$ Bench vice, FUKUNG Brand made in The People's Republic of China. The seeds were milled using magic blender, SHB-515 model made by Sorex Company Limited, Seoul, Korea. Stock of Aspergillus niger was obtained from the Plant Health Management Department of International Institute of Tropical Agriculture (IITA), Ibadan, Nigeria.

Milled sample of Terminalia catappa seed was inoculated with spores of $A$. niger and fermented for three weeks as described by Muhammad and Oloyede (2006). The fermented substrate was oven-dried at $60{ }^{\circ} \mathrm{C}$ for 48 hours to kill the $A$. niger and the dried substrate was used as a source of protein in formulating diet as shown in Table 1 . Proximate analysis of the formulated feed was carried out as described in AOAC (1990). The metabolisable energy was obtained as described by Pike and Brown (1975).

Forty-five (45) day-old broiler chicks of both sexes (average initial weight $30.25 \pm 2.40 \mathrm{~g}$ ) were randomly assigned into three (3) dietary treatment groups. Each treatment had three replicates with five birds per replicate. The broilers were kept in an environment that is warm $\left(40-45^{\circ} \mathrm{C}\right)$ and disinfected. The animals were allowed to acclimatize to the laboratory environment for one week. The birds were weighed prior to the commencement of the feeding experiment and thereafter on weekly basis for seven (7) weeks. Group feeding was carried out and the animals were supplied feed and water $a d$ libitum. The feed supplied and the remnants were weighed daily. Appropriate medications and vaccinations were administered at the $1^{\text {st }}$, $2^{\text {nd }}$ and $3^{\text {rd }}$ week of the feeding trial. At the 
end of the feeding trial, the birds were sacrificed and their organs weighed. The organ to body weight ratios was also calculated.

\section{RESULTS}

The proximate composition of the diet is shown in Table 2. There were no significant differences $(p>0.05)$ in the quantity of nutrients of the various diets. The growth performance characteristics of the broilers placed on the diets are shown in Table 3 . The feed intake of the broilers placed on the $A$. niger fermented $T$. catappa seed meal-based diet was significantly increased over those placed on the raw T. catappa seed meal-based diet. The control has the highest feed intake. The growth response curves of the experimental animals are shown in Figure 1. The broiler placed on the A. niger fermented T. catappa seed meal-based diet had higher growth rate than those placed on the raw $T$. catappa seed meal-based diet. The organ to body weight ratios of the broilers placed on the different diets are shown in Table 4. When compared with those on the control and the fermented $T$. catappa seed meal-based diets, the organ to body weight ratio of the liver and gizzard of the animals reared on the raw $T$. catappa seed meal-based diet was significantly higher $(\mathrm{p}<0.05)$.

\section{DISCUSSION}

The results of the proximate analysis of the formulated feed (Table 2) showed that the various diets formulated are isocaloric and isonitrogenous. Therefore, there is basis for comparison of the different effects of the quality of the feed on the experimental animals.

The significant increase in the feed intake of the animals fed the fermented $T$. catappa seed meal-based diet compared to those on the raw $T$. catappa seed meal-based diet (Table 3) may be an indication of reduction in the level of tannins in the fermented sample. Tannins are known to cause reduction in feed intake (probably by irritating the gut) due their astringency or bitter taste, thereby reducing the palatability of the feed (Reed, 1995). Our earlier study had confirmed a significant reduction in the tannin content of $T$. catappa seed meal when fermented using A. niger (Muhammad and Oloyede, 2006).

Table 1: Percentage composition of the diets (g/100 g).

\begin{tabular}{lccc}
\hline Ingredients & A & B & C \\
\hline Maize & 47 & 32 & 49 \\
Soybean meal & 35 & - & - \\
Raw T. catappa seed meal & - & 50 & - \\
Fermented T. catappa seed meal & - & - & 33 \\
Maize bran & 6.00 & 6.00 & 6.00 \\
Wheat offal & 8.00 & 8.00 & 8.00 \\
Bone meal & 2.54 & 2.54 & 2.54 \\
Oyster shell & 1.00 & 1.00 & 1.00 \\
NaCl & 0.2 & 0.2 & 0.2 \\
*Vit/Min premix & 0.25 & 0.25 & 0.25 \\
Lysine & 0.01 & 0.01 & 0.01 \\
Methionine & 0.01 & 0.01 & 0.01 \\
\hline Total & $\mathbf{1 0 0}$ & $\mathbf{1 0 0}$ & $\mathbf{1 0 0}$
\end{tabular}

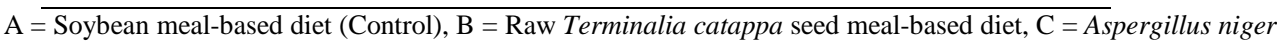
treated Terminalia catappa seed meal-based diet. *Vit. A, 4,000,000 IU; Vit. $\mathrm{D}_{3}, 800,000 \mathrm{IU}$; Tocopherols, 4,000 IU; Vit. $\mathrm{K}_{3}, 800 \mathrm{mg}$; Folacin, $200 \mathrm{mg}$; Thiamine, $600 \mathrm{mg}$; Riboflavin, 1,800 mg; Niacin, 6,000 mg; Calcium Panthothenate, 2,000 mg; Pyridoxine, $600 \mathrm{mg}$; Cyanocobalamin, $4 \mathrm{mg}$; Biotin, $8 \mathrm{mg}$; Manganese, 30,000 mg; Zinc, 20,000 mg; Iron, 8,000 mg; Choline chloride, 80,000 mg; Copper, 2,000 mg; Iodine, $480 \mathrm{mg}$; Cobalt, 80 $\mathrm{mg}$; Selenium, $40 \mathrm{mg}$; BHT, 25,000; Anticaking agent, 6,000 mg. 
Table 2: Percentage proximate composition of the formulated diet.

\begin{tabular}{lccc}
\hline Parameters & Control & Raw T. catappa & A. niger treated T. catappa \\
\hline Dry Matter (\%) & $96.35 \pm 2.64$ & $97.02 \pm 2.38$ & $96.65 \pm 2.87$ \\
Crude Protein (\%) & $21.25 \pm 0.35$ & $20.89 \pm 0.40$ & $21.00 \pm 0.32$ \\
Ether extract (\%) & $5.82 \pm 0.34$ & $6.25 \pm 0.15$ & $6.21 \pm 0.17$ \\
Crude fibre (\%) & $7.10 \pm 0.12$ & $6.93 \pm 0.09$ & $6.89 \pm 0.15$ \\
Ash content (\%) & $6.75 \pm 0.05$ & $6.70 \pm 0.06$ & $6.72 \pm 0.03$ \\
N.F.E (CHO) (\%) & $59.09 \pm 0.07$ & $59.23 \pm 0.05$ & $59.17 \pm 0.05$ \\
Calorific value $(\mathrm{kcal} / 100 \mathrm{~g})$ & $373.74 \pm 4.86$ & $376.73 \pm 3.49$ & $376.57 \pm 3.65$ \\
\hline
\end{tabular}

Values are means of 4 determinations \pm SD.

Table 3: Performance characteristics of broiler chicks fed A. niger fermented T. catappa seed mealbased diet for 7 weeks.

\begin{tabular}{lccc}
\hline Parameters & Control & Raw T. catappa & $\begin{array}{c}\text { A. niger fermented } \\
\text { T. catappa }\end{array}$ \\
\hline Av. Feed Intake (g/bird/wk) & $36.30 \pm 1.58^{\mathrm{a}}$ & $11.03 \pm 0.03^{\mathrm{b}}$ & $15.91 \pm 0.02^{\mathrm{c}}$ \\
Av. Initial Weight & $30.44 \pm 2.41^{\mathrm{a}}$ & $30.30 \pm 2.97^{\mathrm{a}}$ & $30.20 \pm 3.38^{\mathrm{a}}$ \\
Av. Final Weight & $605.25 \pm 39.88^{\mathrm{a}}$ & $117.00 \pm 10.46^{\mathrm{b}}$ & $185.44 \pm 12.24^{\mathrm{c}}$ \\
Av. Weekly weight gain (g/bird/wk) & $82.12 \pm 6.45^{\mathrm{a}}$ & $12.39 \pm 1.46^{\mathrm{b}}$ & $32.18 \pm 1.67^{\mathrm{c}}$ \\
Av. Daily weight gain (g/bird/day) & $11.73 \pm 1.26^{\mathrm{a}}$ & $1.77 \pm 0.24^{\mathrm{b}}$ & $3.17 \pm 0.32^{\mathrm{c}}$ \\
Feed Conversion Ratio & $0.44 \pm 0.06^{\mathrm{a}}$ & $0.89 \pm 0.06^{\mathrm{b}}$ & $0.49 \pm 0.08^{\mathrm{c}}$ \\
$\%$ Mortality ratio & - & 13.33 & - \\
\hline Values are means of 12/15 birds \pm SD. Row values with the different superscripts are significantly $(\mathrm{p}<0.05)$ different.
\end{tabular}

Also, the significant improvement observed in the feed conversion ratio of the birds placed on the fermented T. catappa seed meal-based diet, when compared with those on the raw T. catappa seed meal-based diet, is indicative of a better utilization of the feed. Feed conversion ratio is the amount of feed consumed per unit weight gain (Atteh, 2004). It showed that the animals, reared on the feed, gained more weight with little amount of the feed consumed. Earlier research work, using rats and goats, have shown that fungi treatedfeed materials do increase the feed conversion ratio of animals reared on such materials (Jacqueline et al., 1996; Muhammad et al., 2000; Belewu and Adeniyi, 2001; Belewu et al., 2002; Belewu et al., 2006).

The significant increase in the final average live weights and the improvement in the growth performance of the broilers placed on the fermented $T$. catappa seed meal-based diet (Table 3 and Figure 1) is an indication of an increase in the bioavailability and better utilization of the nutrients in the feed. Antinutritional factors are known to form insoluble complexes with carbohydrates, proteins, polysaccharides, enzymes involved in protein and carbohydrate digestion, thereby affecting their digestibility and bioavailability (Haslam, 1989; Reed, 1995; Giner-Chavez, 1996).

The breakdown of these complexes (Muhammad and Oloyede, 2006) by the hydrolytic enzymes (among which are pectinases, carbohydrases, phytases, amylases, amyloglucosidase, lactase, invertase, and acid proteases) produced by the A. niger (Bennett, 1985; Ward, 1989; Sani et al., 1992; Wyss et al., 1998; Nagashima et al., 1999), would enhance protein digestibility and mineral bioavailability. These two classes of nutrients, proteins and minerals, are very crucial to the 


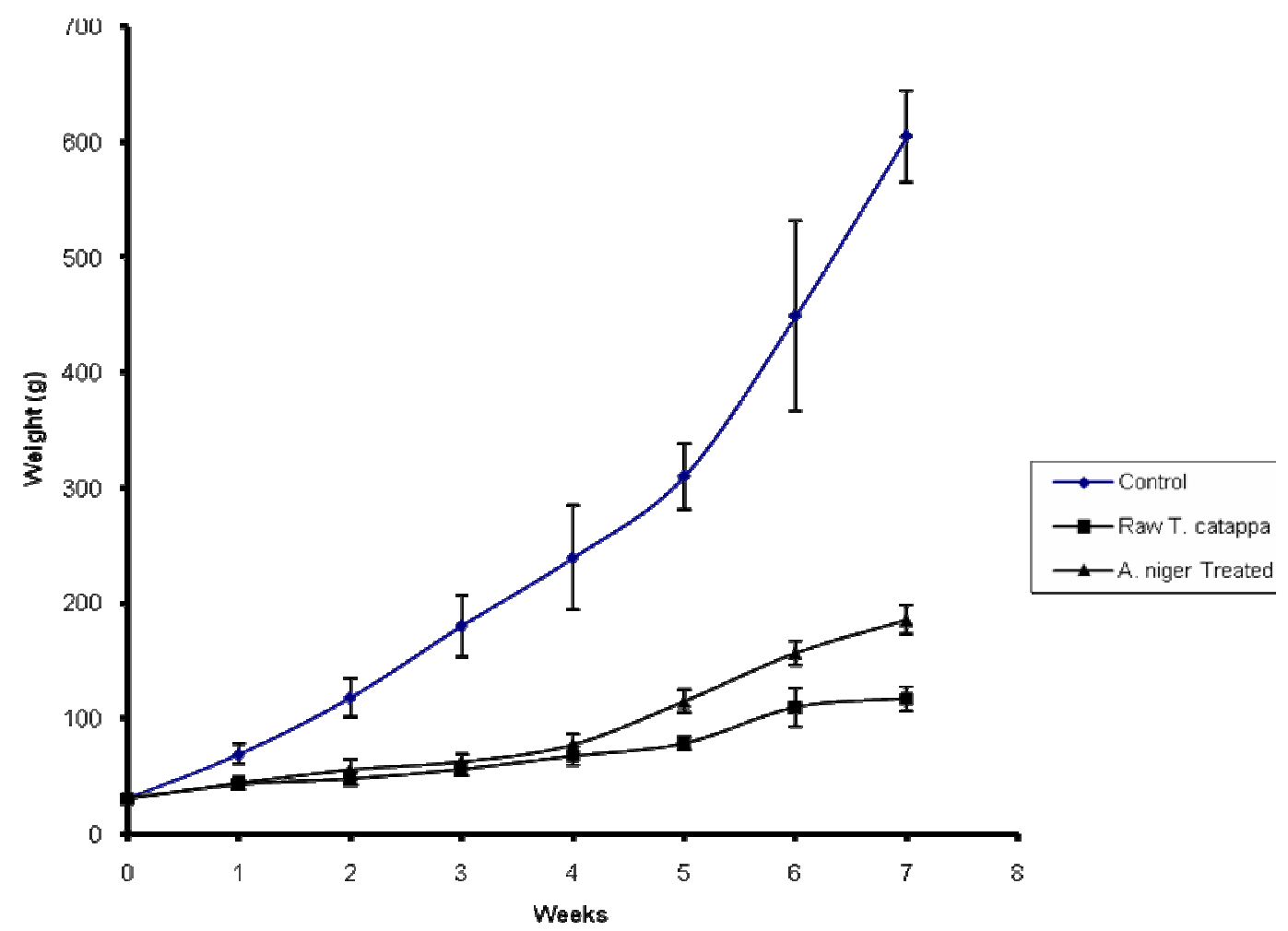

Figure 1: Growth performance curve of broiler chicks fed Aspergillus niger treated Terminalia catappa seed meal-based diet for 7 weeks. Plotted values are means of 9 birds \pm SEM.

Table 4: Percentage organ to body weight ratio of broiler chicks fed A. niger fermented $T$. catappa seed meal-based diet for 7 weeks.

\begin{tabular}{lccc}
\hline Organ & Control & Raw T. catappa & A. niger fermented T. catappa \\
\hline Liver & $2.48 \pm 0.08^{\mathrm{a}}$ & $3.16 \pm 0.02^{\mathrm{b}}$ & $2.62 \pm 0.07^{\mathrm{a}}$ \\
Heart & $0.62 \pm 0.02^{\mathrm{a}}$ & $1.26 \pm 0.01^{\mathrm{b}}$ & $1.24 \pm 0.03^{\mathrm{b}}$ \\
Gizzard & $3.76 \pm 0.05^{\mathrm{a}}$ & $5.33 \pm 0.03^{\mathrm{b}}$ & $5.05 \pm 0.02^{\mathrm{c}}$ \\
Crop & $1.03 \pm 0.05^{\mathrm{a}}$ & $0.88 \pm 0.05^{\mathrm{b}}$ & $0.81 \pm 0.04^{\mathrm{b}}$ \\
\hline
\end{tabular}

Values are means of 9 determinations \pm SD. Row values with the different superscripts are significantly $(\mathrm{p}<0.05)$ different.

growth, development and maintenance of the good health of animals (Iherekonye and Ngoddy, 1985; Nelson and Cox, 2005).

Furthermore, the present result showing no mortality in the group of animals fed the $A$. niger-fermented T. catappa seed meal-based diet (Table 3), is an indication that most of the antinutrients in the T. catappa seed meal have been eliminated or significantly reduced.
Some of these antinutrients are known to cause death in animals. Tannins complex with and reduced absorption of $\mathrm{Fe}$ in the gut (Butler, 1989, 1992). Phytate is known to complex with protein thereby reducing their digestibility. It has also been reported to chelate with divalent ions like $\mathrm{Fe}^{2+}, \mathrm{Mn}^{2+}$, $\mathrm{Zn}^{2+}, \mathrm{Mg}^{2+}$ etc reducing their bioavailability in the body. The reduction in the bioavailability 
of these vital ions, in part, may be responsible for the death of these animals. Cyanide, which is also present in T. catappa seed, is a harmful ion that is hazardous to life. It forms a very stable complex with metals (e.g. Fe and $\mathrm{Mg}$ ) at the active site of enzymes, thereby inhibiting vital functions in cells such as respiration and protein synthesis (West et al., 1966; Voet and Voet, 1995; ATSDR, 1997, 2004).

Of the various organs selected, only the liver and gizzard were significantly affected (Table 4). Organ to body weight ratio gives a proportional size of the organ with respect to the body. The liver, being the major organ carrying out metabolic and detoxification processes, may have been inflamed due to the apparent toxicity of the raw T. catappa seed meal, which may lead to hepatic cell damage (Muhammad and Oloyede, 2004; Muhammad et al., 2006). The gizzard, being a muscularized organ and a place where food particles sojourn for a period of time while undergoing digestion, may also be expanding to cope with the grinding of the complexes formed by the antinutrients with the food nutrients, thus the enlargement of the organ.

Though, only the broilers fed the control (soybean-based) diet met the recommended weight by earlier workers (North, 1984; Summers and Lesson, 1985), the present result on the broilers fed the $A$. niger-fermented $T$. catappa seed meal-based diet showed an improved performance over those placed on the raw T. catappa seed mealbased diet. Therefore, it is considered that the use of $A$. niger-fermented T. catappa seed meal as protein source for broiler feeds would enhance growth performance and prevent mortality.

\section{REFERENCES}

Aderibigbe AO, Johnson COLE, Makkar HPS, Becker K, Foidl N. 1997. Chemical composition and effect of heat on organic matter- and nitrogen-degradability and some antinutritional components of Jatropha meal. Animal Feed Science Technology, 67: 223 - 243.

Adewole A, Olowookere JO. 1986. Nutritional potentialities of Irvingia gabonensis and Terminalia catappa fruits. Nutri. Repts Intern., 2: 10 - 13.
AOAC. 1990. In Official Methods of Analysis $\left(15^{\text {th }}\right.$ edn). Association of Official Analytical Chemists: Washington, D.C.

ATSDR (Agency for Toxic Substances and Disease Registry). 1997. Managing Hazardous Materials Incidents. Volume III - Medical Management Guidelines for Acute Chemical Exposures: Cyanide. Atlanta, GA: U.S. Department of Health and Human Services, Public Health Service.

ATSDR (Agency for Toxic Substances and Disease Registry). 2004. Toxicological profile for cyanide. (Draft for Public Comment). Atlanta, GA: U.S. Department of Health and Human Services, Public Health Service.

Atteh JO. 2002. Principles and Practice of Livestock Feed Manufacturing. ADLEK Printers: Ilorin, Nigeria.

Atteh JO. 2004. Theory and Practice of Poultry Production. ADLEK Printers: Ilorin, Nigeria.

Beecher GR. 2003. Over view of dietary flavonoids: nomenclature, occurrence and intake. J. Nutr., 133(10): 3248S-3254S.

Belewu MA, Adeniyi AO. 2001. Apparent digestibility of solid state fermentation of cotton waste with fungus Pleurotus sajor caju, using West African Dwarf goats NISEB Journal, 1(2): 123 -128.

Belewu MA, Belewu KY, Lawal RO, Oyerinde AA, Salami OS. 2006. A Review of Agricultural Biotechnology: Potentials and Limitations in Africa. African Journal of General Agriculture, 2(1): $29-35$.

Belewu MA, Yousuf MB, Aderolu ZO, Fawole OB, Ajibade AO. 2002. Enrichment of rice husk by fermentation with macro and micro fungi for livestock feed. Proc. $7^{\text {th }}$ Ann. Conf., Anim. Sci. Ass. of Nig. (ASAN) Sept. 16 - 19, 2002. Univ. of Agric., Abeokuta, Nigeria.

Bennett JW. 1985. Taxonomy of fungi and biology of the Aspergilli. In Biology and Industrial Microorganisms, Demain AL, Solomon NA (eds). Benjamin Cummings Publishing Co: Menlo Park, CA.

Butler LG. 1989. Effects of condensed tannins on animal nutrition. In Chemistry and Significance of Condensed Tannins, Hemingway, Karchesy (eds). Plennum Press: New York; 391 - 402. 
Butler LG. 1992. Antinutrient effect of condensed and hydrolyzable tannins. Basic Life Sci., 59: 693-698.

Chavan JK, Kadam SS. 1989. Nutritional improvement of cereals by fermentation. Crit. Rev. Food Sci. Nutr. 28(5): 349400.

Chen PS, Li JH, Liu TY, Lin TC. 2000. Terminalia catappa and its major tannin component, punicalagin, are effective against bleomycin-induced genotoxicity in Chinese hamster ovary cells. Cancer Lett., 152(2): 115 - 122.

Classen HI, Cooper R. 1998. Improving animal feeding through enzyme use. Feed Notes, 1(3). A publication of Praire Feed Resource Centre, Saskatoon, Canada.

Gilani GS, Cockell KA, Sepehr E. 2005. Effects of antinutritional factors on protein digestibility and amino acid availability in foods. J. AOAC. Int., 88(3): 967-87.

Giner-Chavez BI. 1996. Condensed tannins in tropical forages. Ph.D Thesis, Cornell University, Ithaca, NY, USA.

Haslam E. 1989. Plant Polyphenols. Cambridge University Press: Cambridge, UK.

Hotz C, Gibson RS. 2007. Traditional foodprocessing and preparation practices to enhance the bioavailability of micronutrients in plant-based diets. $J$. Nutr., 137(4): 1097-1100.

Ihekoronye AI, Ngoddy PO. 1985. Integrated Food Science and Technology for the Tropics. Macmillan Education Limited: London and Oxford.

Jacqueline EW, Broerse Bert V. 1996. Assessing the Potential in Biotechnology: Building on Farmers' Knowledge, Joske Bunders, Bertus Haverkorf, Wim Hiemstra (eds). Published by Macmillan Education Ltd: London and Basingstoke.

Jeremiah EA. 1992. Chemical evaluation of the nutritional quality of almond fruit (Terminalia catappa). In Nutritional Quality of Plant Foods, Osagie AU, Eka OU (eds). Published by Post Harvest Research Unit: University of Benin, Nigeria; 93.

Kamra DN. 2005. Rumen microbial ecosystem. Current Science., 89(1): 124 135.
Lin CC, Hsu YF, Lin TC. 1999. Effects of punicalagin and punicalin on carrageenan-induced inflammation in rats. Am. J. Clin. Med., 27(3-4): 371-376.

Mohan VR, Janardhanan K. 1995. Chemical analysis and nutritional assessment of lesser known pulses of the genus Muccuna. Food Chemistry. 52: 275-280.

Muhammad NO, Adeyina AO, Peters OM. 2000. Nutritional evaluation of fungi treated cocoa bean shell. Nig. J. Pure Appl. Sci., 15: 1059-1064.

Muhammad NO, Oloyede OB. 2004. Assessment of Biological value of Terminalia catappa seed meal-based diet in rats. Biokemistri, 16(1): 49-55.

Muhammad NO, Oloyede OB. 2006. Effects of solid state fermentation on the levels of some nutrients and antinutrients of Terminalia catappa seed meal. Nig. J. Biochem. Mol. Biol., 21(2): In Press.

Muhammad NO, Oloyede OB. 2009. Protein fractions and amino acid profile of Aspergillus niger-fermented Terminalia catappa seed meal. African J. Microbiology Research, 3(3): 101 - 104.

Nagashima T, Tange T, Anazawa H. 1999. Dephosphorylation of phytate using the Aspergillus niger phytase with a affinity for phytate. Applied and Environmental Microbiology, 65(10): 4682-4684.

Nelson DC, Cox MM. 2005. Lehninger Principles of Biochemistry ( $4^{\text {th }}$ edn). W.H. Freeman and Co: New York.

North MO. 1984. Commercial Chicken Production Manual ( $3^{\text {rd }}$ edn). AVI Publishing Company: Westport.

Oboh G, Oladunmoye MK. 2007. Biochemical changes in micro-fungi fermented cassava flour produced from low- and medium-cyanide variety of cassava tubers. Nutr. Health., 18(4): 35567.

Osagie AU. 1998. Antinutritional factors. In Nutritional Quality of Plant Foods, Osagie AU, Eka OU (eds). Post Harvest Research Unit, University of Benin: Nigeria; 221-224.

Phillips RD. 1993. Starchy legumes in human nutrition, health and culture. Plant Foods Hum Nutr, 44(3): 195-211.

Pike RC, Brown MC. 1975. Nutrition, an Integrated Approach ( $2^{\text {nd }}$ edn). John Wiley and Sons Inc.: New York. 
Reddy NR, Sathe SK. 2002. Food Phytates. CRC Press: Boca Raton, Florida.

Reed JD. 1995. Nutritional toxicology of tannins and related polyphenols in forage legumes. J. Anim. Sci., 73: 1516 - 1528.

Sani A, Awe FA, Akinyanju JA. 1992. Amylase synthesis in Aspergillus flavus and Aspergillus niger grown on cassava peel. J. Ind. Microbiol., 10: 55 - 59.

Summers JD, Lesson S. 1985. Poultry nutrition handbook. Office for Educational Practice, University of Guelph, Ontario, Canada.

Voet D, Voet JG. 1995. Biochemistry (2 ${ }^{\text {nd }}$ edn). Published by John Wiley and Sons: Inc., New York.
Ward OP. 1989. Fermentation Biotechnology. Prentice Hall: Englewood Cliffs.

West ES, Todd WR, Mason HS, Van Bruggen JT. 1966. Biochemistry (4 ${ }^{\text {th }}$ edn). The Macmillan Company, Collier-Macmillan Canada Ltd.: Toronto, Ontario.

Wyss M, Pasamontes L, Remy R, Kohler J, Kusznir E, Gadient M, Muller F, van Loon APGM. 1998. Comparison of the thermostability properties of three acid phosphatases from molds: Aspergillus fumigatus phytase, A. niger phytase, and A. niger $\mathrm{pH} 2.5$ acid phosphatase. Applied and Environmental Microbiology, 64(11): 4446 - 4451. 